DOI https://doi.org/10.30525/978-9934-26-182-4-17

\title{
ФАКТОРИ РИЗИКУ ТЯЖКОГО ПЕРЕБІГУ COVID-19 У ПАЦІЕНТІВ, ЯКІ ЛІКУЮТЬСЯ МЕТОДОМ ГЕМОДІАЛІЗУ
}

\author{
Рисев А. В. \\ медичний директор \\ Медичний иенттр ТОВ «Лінк-Медітал» \\ м. Одеса, Украӥна \\ Степанова Н. М. \\ доктор медичних наук, професор, \\ завідувач відділу нефрології та діалізу \\ Державна установа «Інститут нефрології \\ Національної академії медичних наук України» \\ Медичний центр ТОВ «Нефрочентр», м. Київ, Запоріжжя, Львів
}

Остапенко T. I.

кандидат медичних наук,

заступник медичного директора

Медичний центр ТОВ «Нефрочентр», м. Київ, Запоріжж, Львів

Русин О. I.

заступник медичного директора

Медичний цеентр ТОВ «Нефрочентр», м. Київ, Запоріжжя, Львів

Компанісць О. Л.

молодиий науковий співробітник,

лікар-нефролог

Державна установа «Інститут нефрологіі

Національної академії медичних наук Украӥни»

м. Київ, Україна

\section{Снісар Л. М.}

кандидат медичних наук,

провідний науковий співробітник

Медичний иентр ТОВ «Нефроиентр», м. Київ, Запоріжжя, Львів

Державна установа «Інститут нефрологіі

Національної академії медичних наук України»

м. Київ, Україна

Вступ. Пацієнти з хронічною хворобою нирок VД стадії, які лікуються методом гемодіалізу (ГД) особливо вразливі до інфікування SARS-CoV-2 
i мають високий ризик тяжкого перебігу COVID-19 та смертності. Попередні дані продемонстрували, що рівень смертності у ГД пацієнтів інфікованих SARS-CoV-2 коливався від 6,5 до 52\%, що значно вище, ніж у загальній популяції $[1,2]$. Саме тому, метою нашої роботи було ретроспективно оцінити взаємозв'язок між показниками адекватності ГД, тяжкістю перебігу COVID-19 та смертністю ГД пацієнтів.

Методи. До цього ретроспективного когортного дослідження було залучено 340 пацієнтів з 5 діалізних центрів різних регіонів України, віком $53,5 \pm 12,9$ років і тривалістю діалізної терапії 40 [24-74] місяців. Тяжкий перебіг COVID-19 визначали за необхідності госпіталізації та кисневої підтримки пацієнта.

Дані представлені як середнє значення та квадратичне відхилення $(\mathrm{M} \pm \mathrm{SD})$ або медіана та інтерквартильний діапазон (Me (Q25-Q75)) та порівняні за допомогою тесту Краскала-Уолліса. Для визначення відмінностей між категоріальними змінними використовувався критерій $\chi^{2}$-квадрат. Фактори ризику тяжкого перебігу COVID-19 визначали за допомогою логістичного регресійного аналізу.

Результати. Серед включених у дослідження пацієнтів було 312 $(91,7 \%)$ хворих, які отримували лікування методом гемодіафільтрації (ГДФ) і 28 (8,3\%) пацієнтів, які лікувались методом ГД. Стать $\left(\chi^{2}=1,12\right.$, $\mathrm{p}=0,29)$, вік $(55,3 \pm 12,9$ проти $59,6 \pm 12,5$ років, $\mathrm{p}=0,07)$ і тривалість лікування ГД (40 [23-72] проти 45 [29-84] місяців, $\mathrm{p}=0,39)$ не відрізняються між групами ГДФ та ГД. Протягом періоду спостереження 114 (36,5\%) були інфіковані COVID-19, серед яких 66 (59\%) потребували госпіталізації та кисневої підтримки та 9 (8\%) пацієнтів померло. За результатами логістичного регресійного аналізу вік пацієнтів понад 60 років (OR 1,03 95\% ДI 1,01; 1,05), діабетичний статус (OR 2,8 95\% ДI $1,4 ; 5,5)$, тривале лікування ГД (OR 1,07 95\% ДI 1,03; 1,1), низький рівень ліпопротеїдів високої щільності (ЛПВЩ) (OR 1,7 95\% ДІ 1,2; 3,4) i високий C-реактивний протеїн до інфікування SARS-CoV-2 (OR 1,6 95\% ДI 1,1; 5,7), а також низька швидкість потоку крові (OR 1,04 95\% ДI 1,02; $1,08)$ та лікування ГД порівняно з ГДФ (OR 4,1 95\% ДI 1,5; 11,2) були статистично значущо асоційовані з тяжким перебігом COVID-19 та потребою в кисневій підтримці.

Висновки. Вік старше 60 років, цукровий діабет, тривале лікування діалізною нирковою замісною терапією, низький рівень ЛПВЩ, високий С-реактивний протеїн крові до інфікування та лікування ГД з низькою швидкістю потоку крові достовірно асоціювались 3 тяжким перебігом COVID-19 та необхідністю кисневої підтримки у нашій когорті ГД пацієнтів. 


\begin{abstract}
Література:
1. Ma Y, Diao B, Lv X, et al. Epidemiological, clinical, and immunological features of a cluster of COVID-19-contracted hemodialysis patients. Kidney Int Rep. 2020;5(8):1333-1341.

2. Valeri AM, Robbins-Juarez SY, Stevens JS, et al. Presentation and outcomes of patients with ESKD and COVID-19. J Am Soc Nephrol. 2020;31(7):1409-1415.
\end{abstract}

DOI https://doi.org/10.30525/978-9934-26-182-4-18

\title{
РАЦІОНАЛЬНЕ ЗАСТОСУВАННЯ ТОПІЧНИХ КОРТИКОСТЕРОЇДІВ ДЛЯ ЗОВНІШНЬОЇ ТЕРАПІЇ ПСОРІАЗУ
}

\author{
Рябова О. О. \\ кандидат медичних наук, доиент, \\ дочент закладу вищої освіти кафедри фармакології \\ та фармакотерапії \\ Національний фармачевтичний університет \\ Кашута В. $\mathbf{\epsilon}$. \\ кандидат медичних наук, доиент, \\ доцент закладу вищої освіти кафедри фармакології \\ та фармакотерапії \\ Наџіональний фармацевтичний університет \\ м. Харків, Украӥна
}

На сьогоднішній день псоріаз $\epsilon$ актуальною медико-соціальною проблемою. Поширеність захворюваності на псоріаз серед осіб будь-якого віку, тривалі рецидиви дерматозу, повна або часткова втрата працездатності, високі рівні інвалідизації, що супроводжуються соціальнопсихологічною дезадаптацією пацієнтів, обумовлюють актуальність проблеми псоріазу [1, с.10].

Псоріаз розглядають як полісистемне, генетично детерміноване, хронічне, рецидивуюче захворювання організму багатофакторної природи, що характеризується імунозалежним запаленням, доброякісною гіперпроліферацією епідермальних клітин з аномальною їх диференціацією та супроводжується папуло-сквамозними висипаннями, стадійністю, 